\title{
S100 protein content of umbilical cord blood in healthy newborns in relation to mode of delivery
}

\author{
J W Wirds, A E J Duyn, S D Geraerts, E Preijer, J A A M van Diemen-Steenvoorde, \\ J H Schagen van Leeuwen, F J L M Haas, W B M Gerritsen, A de Boer, J A Leusink
}

Arch Dis Child Fetal Neonatal Ed 2003;88:F67-F69

See end of article for
authors' affiliations
$\ldots \ldots \ldots \ldots \ldots \ldots \ldots \ldots \ldots$
Correspondence to:
Dr Wirds, PO Box 2500,
3430 EM Nieuwegein, The
Netherlands;
jwwirds@planet.nl
Accepted 29 April 2002

\begin{abstract}
Background: Early detection and quantification of brain damage in neonatal asphyxia is important. In adults, S100 protein in blood is associated with damage to the central nervous system. Objective: To determine whether S100 protein can be detected in arterial and venous cord blood of healthy newborns and to relate $\mathrm{S} 100$ protein concentrations in cord blood to mode of delivery.

Method: S100 protein levels in umbilical cord blood of 81 healthy infants were determined. Results: S100 protein was present in arterial (median concentration $1.62 \mathrm{\mu g} / \mathrm{l}$ ) and venous (median concentration $1.36 \mu \mathrm{g} / \mathrm{l}$ ) cord blood. Levels were significantly higher in vaginal births (median arterial concentration $1.72 \mathrm{\mu g} / \mathrm{l}$; median venous concentration $1.48 \mathrm{\mu g} / \mathrm{l}$ ) than births by caesarean section $(1.51 \mu \mathrm{g} / \mathrm{l}$ and $1.26 \mathrm{\mu g} / \mathrm{l}$ respectively).

Conclusion: More research is necessary to determine whether $\mathrm{S} 100$ protein is a useful marker in neonatal asphyxia.
\end{abstract}

N eonatal asphyxia can result in extensive brain damage. It is important to be able to detect, predict, and monipossible. tor the development of this damage as early as In adults, attention has been drawn to specific markers for brain damage. The creatine kinase isoenzyme $\mathrm{BB}$ has been studied extensively in this respect. Its concentration in cerebrospinal fluid (CSF) is raised in patients with neurological damage after open heart surgery with cardiopulmonary bypass. ${ }^{1}$ In infants, it is increased in serum after deep hypothermia with circulatory arrest. ${ }^{2}$ A problem is, however, that it can be found in other tissues, for example umbilical cord tissue. This may influence measurements, as Kumpel et $a l^{3}$ have shown.

A second marker, neurone-specific enolase, is found in neurones as an isoenzyme more specific for the brain. The use of neurone-specific enolase as a marker for brain damage is confounded by the fact that there are other large sources of this isoenzyme in the body. It is found in erythrocytes and platelets and it is secreted by certain malignant tumours. ${ }^{45}$

Another possible marker for brain damage is the $\$ 100$ group of proteins. In this article "S100 protein" refers to the $\mathrm{S} 100 \mathrm{a}$ and S100b proteins. S100 protein is a promising marker for damage to the brain in neonates for several reasons. Persson and coworkers ${ }^{6}$ established that CSF S100 protein concentrations reflect the severity of disease in patients suffering from intracerebral haematoma, subarachnoid haemorrhage, and head injury. Another indication for the value of S100 protein in assessing brain damage is the fact that patients who develop cerebral injury as a result of cardiopulmonary bypass surgery have significantly increased concentrations of S100 protein compared with patients without neurological symptoms. ${ }^{7}$ Research has also shown that preterm infants with intraventricular haemorrhage have increased levels of serum S100 protein. ${ }^{8}$ In healthy adults, S100 protein is not detected in the serum. Before determining whether S100 protein can be used as a marker for brain damage in neonatal asphyxia, it is important to know whether it can be found in blood of healthy newborns.

The principal aim of this study was to resolve whether $\$ 100$ protein can be detected in arterial and venous umbilical cord blood of healthy neonates directly after birth. The second intention was to relate the measured quantities of S100 protein to clinical outcome and mode of delivery.

\section{PATIENTS AND METHODS}

Vaginally delivered neonates (spontaneous or by vacuum extraction) and neonates born by caesarean section (elective and emergency) were included in the study over a five month period. Informed consent was obtained from the parents of the subjects before delivery. The local ethics committee approved the study protocol. Children with signs of asphyxia or infection were excluded. Children delivered by caesarean section because of fetal distress before operation were also excluded.

Arterial and venous blood was extracted from the umbilical cord immediately after birth. Upon arrival of the samples in the laboratory, blood gas, lactate, and glucose contents were determined. An arterial and a venous blood sample were subsequently centrifuged, and the supernatants frozen to $-80^{\circ} \mathrm{C}$ to await further analysis of the S100 protein content. S100 protein was measured using a radioimmunoassay (Sangtec 100 IRMA; AB Sangtec Medical, Bromma, Sweden). This assay specifically detects the $\alpha \beta$ and $\beta \beta$ isoforms of the protein. Samples were incubated with plastic beads coated with monoclonal antibodies to which the two isoforms containing the $\beta$ isomer will bind. The beads were washed intensively and the unbound fraction was removed. The beads were then incubated with a second ${ }^{125} \mathrm{I}$ labelled monoclonal antibody against S100. The beads were washed again and unbound radioactive material was removed. Radioactivity bound to the beads was measured using a $\gamma$ counter. The detection limit of this specific test for S100 protein is $0.2 \mu \mathrm{g} / \mathrm{l}$.

Directly after birth, every newborn was given a thorough physical examination by a paediatrician. Apgar scores at one, five, and 10 minutes where recorded.

The data were analysed with SPSS software version 9.0 using Spearman correlation tests and non-parametric MannWhitney U tests. $\mathrm{p}<0.05$ was considered to be significant. All numerical data are presented as medians with the range in quartiles. 


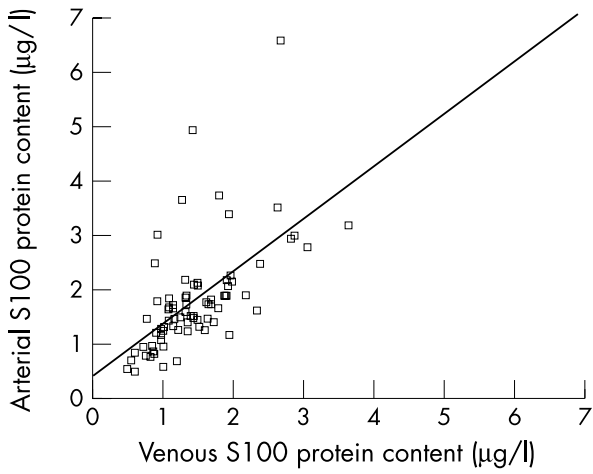

Figure 1 Correlation of $\mathrm{S} 100$ protein concentration in venous and arterial cord blood ( $p<0.01, r=0.60)$.

\section{RESULTS}

Eighty one neonates (4l boys, 40 girls) were included in the study. S100 protein was found in arterial and venous cord blood in all of them. The median concentration was 1.62 (1.25-2.09) $\mu \mathrm{g} / \mathrm{l}$ in arterial cord blood and 1.36 (1.01-1.81) $\mu \mathrm{g} / \mathrm{l}$ in venous cord blood. S100 protein content in venous and arterial umbilical cord blood correlated strongly $(\mathrm{p}<0.01$, $r=0.60$; fig 1).

No significant correlation was found between median S100 protein levels in arterial and venous cord blood of the whole group of neonates and the factors listed in table 1.

In table 1 data were split according to mode of delivery. No statistically significant differences were found between the basic data for the two groups.

S100 protein levels were compared in children born by caesarean section $(\mathrm{n}=30)$ and neonates born vaginally $(\mathrm{n}=51)$. There was a significant difference in arterial $(\mathrm{p}<0.05)$ and venous $(\mathrm{p}<0.05) \mathrm{S} 100$ protein content (fig 2$)$. Venous and arterial lactate and glucose levels were significantly higher after vaginal delivery. Venous and arterial base excess and arterial $\mathrm{pH}$ were significantly lower after vaginal delivery. There was no significant difference between these two groups with respect to Apgar scores or venous $\mathrm{pH}$. There was also no significant difference between S100 levels in infants delivered by caesarean section under general anaesthesia (arterial $1.57(0.97-1.79) \mu \mathrm{g} / \mathrm{l}$; venous 1.10 (0.82-1.65)

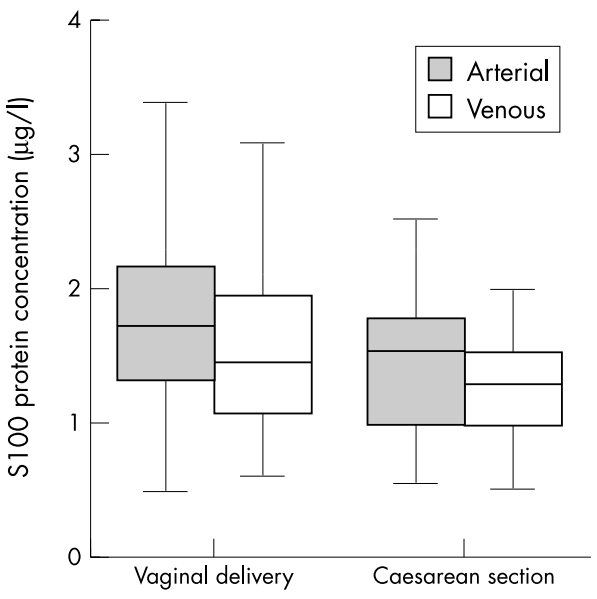

Figure 2 Arterial and venous cord blood serum $\mathrm{S} 100$ concentration according to mode of delivery (median, quartiles, and the highest and lowest values are shown).

$\mu \mathrm{g} / \mathrm{l})$ and caesarean section with spinal anaesthesia (1.50 (1.06-1.75) $\mu \mathrm{g} / \mathrm{l}$ and 1.34 (1.00-1.49) $\mu \mathrm{g} / \mathrm{l}$ respectively). In five cases, epidural analgesia was used. Epidural analgesia did not have an independent impact on S100 protein levels.

Twelve babies were delivered by vacuum extraction. Their serum S100 protein levels did not differ from spontaneous vaginally delivered neonates.

S100 protein content of arterial and venous cord blood was not significantly different between children born by elective (arterial 1.51 (0.97-1.76) $\mu \mathrm{g} / \mathrm{l}$; venous $1.26(0.97-1.50) \mu \mathrm{g} / \mathrm{l}$ ) or emergency (arterial 1.42 (1.00-1.83) $\mu \mathrm{g} / \mathrm{l}$; venous 1.23 (0.831.77) $\mu \mathrm{g} / \mathrm{l}$ ) caesarean section. Arterial and venous $\mathrm{pH}$, base excess, lactate, glucose, Apgar scores, and birth weight were also not significantly different for elective and emergency caesarean section.

\section{DISCUSSION}

This study shows that S100 protein can be detected in cord blood of healthy newborns. The arterial S100 protein concentration was $1.62(1.25-2.09) \mu \mathrm{g} / \mathrm{l}$ and the venous $\mathrm{S} 100$ protein concentration was $1.36(1.01-1.81) \mu \mathrm{g} / \mathrm{l}$.

\begin{tabular}{|c|c|c|c|c|c|}
\hline & \multicolumn{4}{|c|}{ Mode of delivery } & \multirow[b]{3}{*}{$\mathrm{p}$ Value } \\
\hline & \multicolumn{2}{|c|}{ Vaginal delivery $(n=51)$} & \multicolumn{2}{|c|}{ Caesarean section $(n=30)$} & \\
\hline & Median & Quartiles & Median & Quartiles & \\
\hline Maternal age (years) & 32 & $29-34$ & 32 & $28-33$ & 0.34 \\
\hline Maternal weight $(\mathrm{kg})$ & 81 & $72-93$ & 74 & $66-80$ & 0.10 \\
\hline Gestation (days) & 279 & $270-288$ & 272 & $269-284$ & 0.15 \\
\hline Birth weight (g) & 3580 & $3245-3820$ & 3563 & $3135-3985$ & 0.79 \\
\hline Arterial S100 ( $\mu \mathrm{g} / \mathrm{l})$ & 1.72 & $1.31-2.17$ & 1.51 & $0.97-1.76$ & $<0.05$ \\
\hline Venous S100 (pg/l) & 1.48 & $1.08-1.93$ & 1.26 & $0.97-1.50$ & $<0.05$ \\
\hline Apgar $1 \mathrm{~min}$ & 9 & $8-9$ & 9 & $8-9$ & 0.28 \\
\hline Apgar 5 min & 10 & $9-10$ & 10 & $9-10$ & 0.61 \\
\hline Apgar $10 \mathrm{~min}$ & 10 & $10-10$ & 10 & $10-10$ & 0.15 \\
\hline Arterial pH & 7.20 & $7.14-7.25$ & 7.23 & $7.19-7.27$ & $<0.05$ \\
\hline Venous $\mathrm{pH}$ & 7.29 & $7.25-7.34$ & 7.31 & $7.26-7.34$ & 0.84 \\
\hline Arterial BE (mmol/l) & -9 & -11 to -6 & -5 & 0.7 to -3 & $<0.01$ \\
\hline Venous BE (mmol/l) & -7 & -9 to -5 & -4 & -5 to -3 & $<0.01$ \\
\hline Arterial lactate $(\mathrm{mmol} / \mathrm{l})$ & 5.10 & $4.0-6.7$ & 2.50 & $1.9-3.4$ & $<0.01$ \\
\hline Venous lactate (mmol/li) & 4.90 & $3.6-6.1$ & 2.20 & $1.6-2.8$ & $<0.01$ \\
\hline Arterial glucose $(\mathrm{mmol} / \mathrm{l})$ & 4.4 & $3.4-5.0$ & 2.8 & $2.6-3.2$ & $<0.01$ \\
\hline Venous glucose $(\mathrm{mmol} / \mathrm{l})$ & 5.3 & $4.6-5.8$ & 3.7 & $3.2-4.1$ & $<0.01$ \\
\hline
\end{tabular}


Amer-Wåhlin et al $^{9}$ also reported that $S 100$ protein can be detected in cord blood (arterial $1.10(0.38-5.50) \mu \mathrm{g} / \mathrm{l}$; venous $0.98(0.43-2.70) \mu \mathrm{g} / \mathrm{l})$. A new finding in their study was that, in contrast with 5100 protein measurements in adults, ${ }^{10}$ haemolysis can affect measurements in neonates, increasing the concentration. In this study no macroscopic haemolysis was observed.

Maschmann et al ${ }^{11}$ measured serum $\mathrm{S} 100$ protein in blood of healthy newborns (range between 2.5 and 97.5 centile: 0.66$3.33 \mu \mathrm{g} / \mathrm{l}$ ). However, blood was collected at no fixed time points but over several days after birth. This makes it difficult to compare the results with those of our study because S100 protein levels may change in the days after birth.

The second finding is that S100 protein content in cord blood is related to mode of delivery. The content of arterial and venous cord blood is significantly higher in children delivered vaginally than in those delivered by caesarean section. Furthermore, lactate and glucose are higher and base excess and arterial $\mathrm{pH}$ are significantly lower after vaginal delivery compared with caesarean section. These findings indicate that vaginal delivery requires more metabolic adaptation after birth. The fact that the blood gas analysis implies more stress during vaginal delivery may also explain the higher levels of S100 protein in vaginal delivery; more stress and a longer delivery have a significant impact on the central nervous system of the neonate. The difference in S100 protein level between vaginal delivery and caesarean section may also come from differences in head circumference. In spite of the differences in laboratory values, venous $\mathrm{pH}$ and Apgar scores at one, five, and 10 minutes were not different between vaginal delivery and delivery by caesarean section.

As S100 protein has not been used as a marker for central nervous system damage in children, results of measurements of S100 protein in newborns are not easily interpreted. The key to solving this problem may be found in the specific characteristics of the S100 protein. S100 protein has an important function in the growth and development of the cells it is found in. In vitro experiments show that adding S100 protein to glial cells of mice makes them grow profusely. In other cell lines, adding $\mathrm{S} 100$ protein induces apoptosis. ${ }^{12}$

Concentrations of S100 protein in amniotic fluid increase from the 15th week of gestation to the 18th week from 0.45 $\mu \mathrm{g} / \mathrm{l}$ to $0.58 \mu \mathrm{g} / \mathrm{l}^{13} \mathrm{~S} 100$ protein expression in the developing brain of the newborn is much higher than it is in adults. ${ }^{14}$ These factors may account for raised levels of S100 protein in cells of the central nervous system in newborns compared with adults. The fact that S100 protein is found in cord blood in this study is not explained by these factors.

For S100 protein to appear in peripheral blood, two things have to happen. Firstly, S100 protein must be released into the extracellular matrix and from there to the CSF. It is believed that only damage to cells containing S100 protein could account for the appearance of S100 protein in CSF, because in normal circumstances, S100 protein is not found in abundance in the extracellular matrix surrounding cells containing S100 protein. If this is true, why is S100 protein detected in healthy newborns without any neurological problems? Perhaps the S100 protein content of the extracellular matrix is much higher in newborn children. Secondly, S100 protein can only reach the peripheral blood by traversing the blood-brain barrier. Gazzolo et al have postulated that, in newborns, the blood-brain barrier may be immature and therefore more permeable to S100 protein than in adults. This may be one explanation for the raised S100 protein levels in peripheral blood in newborns, if the source of this S100 protein is indeed located primarily in the central nervous system. S100 protein has been detected in various other tissues, although the total amount is small compared with that found in the central nervous system. ${ }^{11}$ Minute amounts have been detected in chondrocytes of adults as well as in fetal cartilage. ${ }^{15}$ S100 protein from other tissues may be an, additional, explanation for the $\mathrm{S} 100$ protein found in peripheral blood in healthy newborns. The only way of determining the source of the S100 protein measured in this study is to simultaneously determine the S100 protein content of CSF and peripheral blood in healthy newborns; this is obviously ethically unacceptable. Therefore we have to use CSF obtained in the course of the treatment of neurological disorders. To our knowledge, S100 protein levels have so far not been determined in CSF of newborns together with the measurement of this level in peripheral blood. It is possible that the origin of some of the S100 protein in cord blood is the placenta. This seems unlikely, however, because the arterial S100 protein concentration is higher than the venous S100 protein level in this study. This also makes maternal blood an unlikely source.

In summary, it is hard to explain the S100 protein levels found in cord blood in this study because the source and the way it enters the peripheral blood of the newborn cannot be reliably determined. It is clear, however, that there is a significant difference in cord blood S100 protein between neonates born by vaginal delivery and those born by caesarean section. The significance of this finding needs to be determined by further research.

\section{Authors' affiliations}

J W Wirds, J A Leusink, Department of Anesthesiology, St Antonius Hospital, Nieuwegein, The Netherlands

A E J Duyn, J H Schagen van Leeuwen, Department of Gynecology and Obstetrics, St Antonius Hospital

S D Geraerts, J A A M van Diemen-Steenvoorde, Department of Pediatrics, St Antonius Hospital

F J L M Haas, W B M Gerritsen, Clinical Laboratory, St Antonius Hospital

E Preijer, A de Boer, Department of Pharmacoepidemiology and Pharmacotherapy, Utrecht Institute of Pharmaceutical Sciences, Utrecht, The Netherlands

\section{REFERENCES}

1 Vaagenes $\mathbf{P}$, Kjekshus J, Sivertsen $E$, et al. Temporal pattern of enzyme changes in cerebrospinal fluid in patients with neurologic complications after open heart surgery. Crit Care Med 1987; 15:726-31.

2 Rossi R, Ekroth R, Thompson R. No flow or low flow? A study of the ischemic marker creatinine kinase BB after deep hypothermic procedures. J Thorac Cardiovasc Surg 1989;98:193-9.

3 Kumpel B, Wood S, Anthony P, et al. Umbilical cord serum creatinine kinase $\mathrm{BB}$ in the diagnosis of brain damage in the newborn: problems in interpretation. Arch Dis Child 1983;58:382-3.

4 Ghandour $\mathbf{M}$, Langley $\mathrm{O}$, Keller A. A comparative immunohistological study of cerebellar enolases. Exp Brain Res 1981;41:271-9.

5 Brown K, Kynoch P, Thompson R. Immunoreactive nervous system specific enolase (14-3-2 protein) in human serum and cerebrospinal fluid. Clin Chim Acta 1980;101:257-64.

6 Persson L, Hårdemark HG, Gustafsson J, et al. S-100 protein and neuron-specific enolase in cerebrospinal fluid and serum: markers of cell damage in human central nervous system. Stroke 1987;18:911-18.

7 Blomquist S, Johnsson P, Lührs K, et al. The appearance of S-100 protein in serum during and immediately after cardiopulmonary bypass surgery: a possible marker for cerebral injury. J Cardiothor Vasc Anesth 1997;1 1:699-703

8 Gazzolo D, Vinesi P, Bartocci M, et al. Elevated $\mathrm{S} 100$ blood level as an early indicator of intraventricular hemorrhage in preterm infant: correlation with cerebral doppler velocimetry. J Neurol Sci 1999;170:32-5

9 Amer-Wåhlin I, Herbst A, Lindoff C, et al. Brain-specific NSE and S-100 proteins in umbilical blood after normal delivery. Clin Chim Acta 2001;304:57-63.

10 Gao F, Harris D, Sapsed-Byrne S. Neurone-specific enolase and Sangtec 100 assays during cardiac surgery. Part III. Does haemolysis affect their accuracy? Perfusion 1997; 12:171-7.

11 Maschmann J, Erb MA, Heinemann MK, et al. Evaluation of protein S-100 concentrations in healthy newborns and seven newborns with perinatal acidosis. Acta Paediatr 2000;89:553-5.

12 Zimmer DB, Cornwall EH, Landar A, et al. The S100 protein family: history, function, and expression. Brain Res Bull 1995;37:417-29.

13 Gazzolo D, Bruschettini M, Corvino V, et al. S100B protein concentrations in amniotic fluid correlate with gestational age and with cerebral ultrasound scanning results in healthy fetuses. Clin Chem 2001;47:954-6.

14 Tiu S, Chan W, Heizmann C, et al. Differential expression of S100B and S100A6 in the human fetal and aged cerebral cortex. Dev Brain Res 2000;1 19:159-68.

15 Stefansson K, Wollmann RL, Moore BW, et al. S-100 protein in human chondrocytes. Nature 1982;295:63-4. 